\title{
Noções de coesão textual na produção escrita de formandos do curso de Letras
}

\author{
Textual cohesion notions in writing \\ production of undergraduate Language \\ students
}

Orlando de Paula*

Universidade de Taubaté

Taubaté - São Paulo / Brasil

\begin{abstract}
RESUMO: Este trabalho tem como objetivo verificar como se manifesta o conceito de coesão textual na produção escrita de formandos do curso de Letras. O corpus sob análise é constituído de 210 textos de alunos de universidades públicas e particulares do Brasil ao responderem à questão de Linguística e Língua Portuguesa da prova do Exame Nacional de Cursos de 2001. Apoia-se, para tanto, no conceito de interacionismo dialógico de Bakhtin e no conceito de heterogeneidade(s) enunciativa(s) de Authier-Revuz, partindo do pressuposto de que o discurso desses acadêmicos se realiza por sujeitos constituídos social e historicamente. De acordo com os resultados, as formas de manifestação de noções de coesão textual ocorrem por meio de marcas relacionadas com o conceito de heterogeneidade mostrada marcada e não marcada com ancoragem em uma concepção tradicional de linguagem.
\end{abstract}

PALAVRAS-CHAVE: dialogismo, heterogeneidade, discurso, coesão textual.

ABSTRACT: This work aims to verify how the concept of textual cohesion is manifested in the written production of undergraduate Language students. The corpus under analysis is constituted of 210 texts written by students from public and private Brazilian universities when answering the question of Linguistics and Portuguese test from the National Courses Examination in 2001. It is theoretically supported by Bakhtinian's concept of dialogic interactionism and by Authier-Revuz concept of enunciative heterogeneity, based on the idea that the students' discourse is historically and socially constructed. The results reveal that the forms of manifestation of textual cohesion notions occur by means of marks related to the marked and unmarked heterogeneity concept based on a traditional view of language. KEYWORDS: dialogism, heterogeneity, discourse, textual cohesion.

*orlpa@uol.com.br ou orlando.paula@unitau.br 


\section{Introdução}

Como se manifesta o conceito de coesão textual no discurso de formandos do curso de Letras? Para responder a essa questão, este trabalho verifica as formas de manifestação sobre coesão textual na produção escrita desses acadêmicos. O percurso metodológico desta pesquisa parte da verificação de como a presença ou a ausência de uma fundamentação teórica sobre coesão textual é marcada na produção escrita desses universitários. Do ponto de vista teórico, esta pesquisa apoia-se no conceito de interacionismo dialógico de Bakhtin $(1997,2003)$ e no conceito de heterogeneidade(s) enunciativa(s) de Authier-Revuz (1990, 2004). Parte do pressuposto de que a manifestação verbal do discurso desses formandos se realiza por sujeitos constituídos social e historicamente e de que esse discurso é constitutivamente heterogêneo. Trata-se de uma perspectiva enunciativo-discursiva, a qual permite lançar um olhar pouco comum sobre o tema, que se caracteriza não só pela análise de marcas linguísticas explícitas, mais afeitas a uma preocupação puramente linguística, mas também, no nível discursivo, pela análise dos efeitos de sentido que essas marcas enunciam. Tais marcas serão vistas como "posicionamento(s) em um campo discursivo" (MAINGUENEAU, 1991, p. 17-18), tomado(s) como indicações das posições teóricas assumidas por esses formandos.

\section{Interacionismo dialógico e heterogeneidade(s) enunciativa(s)}

Entre os vários sentidos e estudos linguísticos apresentados sobre o interacionismo, figura a concepção de interação dialógica e discursiva de Bakhtin e seu círculo. De acordo com essa concepção, a noção de interação está relacionada não apenas com as situações face a face mas também com as situaçōes enunciativas e com os processos dialógicos, pois, segundo Bakhtin/ Volochinov ([1929]1997, p. 112), a "enunciação é o produto da interação de dois indivíduos socialmente organizados [...]”. Mais precisamente, o dialogismo nasce da interação verbal:

$\mathrm{Na}$ realidade, toda palavra comporta duas faces. Ela é determinada tanto pelo fato de que procede de alguém, como pelo fato de que se dirige para alguém. Ela constitui justamente o produto da interação do locutor e do ouvinte. Toda palavra serve de expressão a um em relação ao outro. Através da palavra, defino-me em relação ao outro, isto é, em última análise, em relação à coletividade. A palavra é uma espécie de ponte lançada entre mim e os outros. Se ela se apóia sobre mim numa extremidade, na outra apóia-se sobre o meu interlocutor. 
A palavra é o território comum do locutor e do interlocutor. (BAKHTIN / VOLOCHINOV, [1929] 1997, p. 113).

Bakhtin (2003, p. 274) chama a atenção para a importância do papel de sujeitos ativos, interagindo na / pela linguagem, pois, para ele, o enunciado, como "real unidade da comunicação discursiva", comporta um falante e um ouvinte, como participantes reais da comunicação discursiva. Assim, não se tem um falante ativo e um ouvinte passivo, mas sujeitos atuantes, numa situação real de comunicação discursiva, cuja natureza é ativamente responsiva.

Essa participação responsiva ativa do falante e do ouvinte implica uma atuação interativa, ou, de acordo com a noção de interação de Bakhtin ([1929] 1997, p.123), implica uma relação dialógica interacional entre os interlocutores do discurso e também entre discursos, de tal modo que "A interação verbal constitui [...] a realidade fundamental da língua”.

Para confirmar essa noção de interação e o caráter dialógico, Bakhtin (2003, p. 348) enfatiza a atuação do homem em sociedade e a consciência deste sobre o outro ao tratar da obra de Dostoievski. Opondo-se ao enfoque monológico, continua a discussão sobre o caráter dialógico da linguagem e a tomada de consciência do outro pelo homem:

Natureza dialógica da consciência, natureza dialógica da própria vida humana. A única forma adequada de expressão verbal da autêntica vida do homem é o diálogo inconcluso. A vida é dialógica por natureza. Viver significa participar do diálogo: interrogar, ouvir, responder, concordar, etc. Nesse diálogo o homem participa inteiro e com toda a vida: com os olhos, os lábios, as mãos, a alma, o espírito, todo o corpo, os atos. Aplica-se totalmente na palavra, e essa palavra entra no tecido dialógico da vida humana, no simpósio universal (grifo nosso).

Retomando a discussão sobre as contribuições bakhtinianas para a análise dos textos e dos discursos, Barros (2005, p. 28) afirma que nessa concepção dialógica de linguagem, a alteridade assume papel importante na vida humana, "define o ser humano, pois o outro é imprescindível para a sua concepção: é impossível pensar no homem fora das ligações que o ligam ao outro". O dialogismo é concebido, então, como "o espaço interacional entre o eu e o tu ou entre o eu e o outro, no texto". (BARROS, 1994, p. 3).

Pode-se, então, perceber o destaque dado na obra bakhtiniana às relações dialógicas na discussão sobre o texto e, assim, às duas diferentes concepções de dialogismo, isto é, o diálogo entre interlocutores e o diálogo entre discursos.

Para caracterizar a primeira concepção - o diálogo entre interlocutores -, Barros (2005, p. 29) destaca os seguintes aspectos: 
a) a interação entre interlocutores é o princípio fundador da linguagem $[. .$.$] ;$

b) o sentido do texto e a significação das palavras dependem da relação entre sujeitos, ou seja, constroem-se na produção e na interpretação dos textos;

c) a intersubjetividade é anterior à subjetividade, pois a relação entre os interlocutores não apenas funda a linguagem e dá sentido ao texto, como também constrói os próprios sujeitos produtores do texto;

d) [...] os tipos de sociabilidade podem ser: a relação entre sujeitos (interlocutores que interagem) e a dos sujeitos com a sociedade.

Caracterizando a segunda concepção de dialogismo - diálogo entre discursos -, a autora afirma que Bakhtin considera o dialogismo o princípio constitutivo da linguagem e a condição do sentido do discurso, pois:

- [...] as relaçóes do discurso com a enunciação, com o contexto sócio-histórico ou com o "outro" são, para Bakhtin, relações entre discursos-enunciados;

- [...] o dialogismo tal como foi concebido define o texto como um "tecido de muitas vozes" ou de outros textos ou discursos, que se entrecruzam, se completam, respondem umas as outras ou polemizam entre si no interior do texto. (BARROS, 2005, p. 32-33).

A partir da caracterização do texto como lugar no qual o dialogismo ocorre, texto é definido como um tecido de muitas vozes que se entrecruzam, como criação constitutivamente dialógica que, devidamente contextualizada, tem como produto um objeto único, não reproduzível (BARROS, 2005, p. 33). Essa concepção contempla o diálogo entre interlocutores e também o diálogo entre discursos, uma vez que o discurso não é individual, porque se constrói entre pelo menos dois interlocutores e como um diálogo entre discursos, por isso é impregnado por outras vozes.

Nesse sentido, Authier-Revuz constrói seu conceito de heterogeneidade(s) enunciativa $(s),{ }^{1}$ pois, no princípio dialógico bakhtiniano, a língua só se realiza

\footnotetext{
${ }^{1}$ Além da concepção dialógica bakhtiniana, Authier-Revuz baseou sua teoria nos estudos do discurso e do interdiscurso de M. Pêcheux (1975), C. Fuchs (1981), P. Henry (1977), J. M. Maradin (1979), J. J. Courtine (1981), M. Foucault, L. Althusser (1970), B. Conein et al. (1981), dentre outros. Sobre a abordagem psicanalítica, em J. Lacan (1953; 1957), C. Clément (1973) e E. Roudinesco (1973; 1977).
} 
atravessada por outros discursos, fazendo da "interação com o discurso do outro a lei constitutiva de qualquer discurso" (AUTHIER-REVUZ, 2004, p. 68). Nesse princípio, segundo a autora, duas modalidades de interação, isto é, a interdiscursividade e a interlocução, inscrevem constitutivamente a presença do outro no discurso:

A língua só se realiza atravessada pelas variedades de discursos que se relativizam umas às outras em um jogo inevitável de fronteiras e de interferências;

Nenhuma palavra vem neutra "do dicionário"; elas são todas "habitadas" pelos discursos em que viveram "sua vida de palavras", e o discurso se constitui, pois, por um encaminhamento dialógico, feito de acordos, recusas, conflitos, compromissos... por "meio" dos outros discursos;

Entre esses outros discursos, aquele que o locutor empresta ao interlocutor determina, através de um parâmetro dialógico específico, o processo dialógico de conjunto. (AUTHIER-REVUZ, 2004, p. 68-69).

Com base na psicanálise, na leitura lacaniana de Freud, a autora afirma que a fala do sujeito é fundamentalmente heterogênea e, por isso, torna-se um sujeito dividido, um sujeito que se torna um efeito de linguagem.

O Outro é o lugar estranho, de onde emana todo discurso: lugar da família, da lei, do pai, na teoria freudiana, elo da história e das posiçôes sociais, lugar a que é remetida toda subjetividade: dizer que o inconsciente é o discurso do Outro é reafirmar, de maneira determinista que um discurso livre não existe e é dar-lhe a lei. (CLÉMENT, 1976, p. 117, apud AUTHIER-REVUZ, 2004, p. 64).

Nessa ótica psicanalítica, Authier-Revuz (1990, p. 28) afirma que "sempre sob as palavras, 'outras palavras' são ditas". Trata-se de um sujeito que é o resultado de uma estrutura complexa, que é efeito da linguagem, passando a ser um sujeito descentrado, dividido, clivado. Assim, pode-se escutar no processo discursivo, não intencionalmente, a polifonia de todo discurso.

Apoiada nesses conceitos, Authier-Revuz propõe, então, duas formas de heterogeneidade, isto é, a heterogeneidade mostrada no discurso e a heterogeneidade constitutiva do discurso. No primeiro tipo, formas linguísticas marcadas inscrevem o outro na sequência do discurso como o discurso direto, as aspas, as formas de retoques ou de glosa, etc., ou formas não marcadas como o discurso indireto livre, a imitação, a ironia, etc., causando uma alteração na sua aparente unicidade. 
As formas marcadas, segundo Authier-Revuz (1990, p. 33), representam uma negociação com as forças centrífugas de desagregação, da heterogeneidade constitutiva: elas constroem no desconhecimento desta, uma representação da enunciação, que, por ser ilusória, é uma proteção necessária para que um discurso possa ser mantido. Já as formas não marcadas representam, pelo continuum, a incerteza que caracteriza a referência ao outro, uma outra forma de negociação com a heterogeneidade constitutiva.

No segundo tipo de heterogeneidade, a constitutiva, as formas não são explícitas, mas próprias da natureza da linguagem. Trata-se de formas não marcadas na superfície, mas definidas pela interdiscursividade, ou seja, pela relação que todo discurso mantém com outros discursos.

Portanto, considerando que a interação, no sentido bakhtiniano, está ligada ao funcionamento dialógico da linguagem (diálogo entre interlocutores e entre discursos), pode-se propor, ao menos sob esse aspecto, uma aproximação entre uma concepção interacionista de linguagem e uma concepção de linguagem como constituída pelas heterogeneidades enunciativas.

Nesse sentido, observamos, no objeto de pesquisa deste trabalho, uma manifestação mais próxima (e mais explícita) da noção de heterogeneidade mostrada marcada e caracterizada:

a) pelo uso de palavras e / ou expressões específicas;

b) pelo uso de palavras e / ou expressões não específicas;

c) pelo uso de palavras que não fazem menção nem específica nem não específica à coesão textual.

Observamos também uma manifestação mais velada e, por isso, mais próxima da noção de heterogeneidade mostrada não marcada, caracterizada pelo uso de recursos coesivos, cuja presença também constitui indícios de noções de coesão textual, o que, talvez, represente uma aproximação às determinações do conceito de heterogeneidade constitutiva. Nesse caso, apresentamos uma forma de manifestação de noções de coesão textual caracterizada pelo uso dos recursos coesivos da elipse, da exclusão, da inclusão, da manutenção e da substituição.

\section{Procedimentos metodológicos}

Para compor o corpus desta análise, foram selecionados 210 textos produzidos por formandos do curso de Letras de universidades públicas (UNIPUB) e particulares (UNIPAR) do Brasil ao responderem à questão 
discursiva da prova de Linguística e Língua Portuguesa, do Exame Nacional de Cursos (ENC) 2001, mais conhecido como Provão, o qual foi substituído pelo Exame Nacional de Desempenho de Estudantes-ENADE em 2004. Como essa questão versava sobre o uso de mecanismos coesivos em um texto produzido por uma menina de 10 anos, pressupunha um conhecimento sobre coesão textual. Essa questão apresentava o seguinte enunciado:

QUESTÃO 1-O texto abaixo foi produzido por uma menina de 10 anos.

O outro lado da ilha
Essa história começa com uma família que vai a uma ilha passar suas férias. Quando eles
chegam eles vão logo explorando a ilha e explodem uma barreira que os impediam de passar
para o outro lado da ilha.
Quando eles foram dormir elesperceberam que os bezerros começaram a correr eque quando eles
foram ver o que estava assustando os bezerros. Quando eles de repente, com uma patada só um
caranguejo gigante os atacou. Débora que era sua esposa começou a chorar dizendo que queria
ir embora.
Quando amanheceu eles foram ver como estava o barco, para ir embora eperceberam que
o barco não estava lá. Os homens saíram para explorar a ilha, e no meio do caminho
encontraram um caranguejo que estava no penhasco. Eles não quiseram saber e atiraram no
caranguejo que caiu ribanceira abaixo. Maso marido de Débora, desmaiou e seu irmão não
tinha como ajudá-lo, por isso foi chamar ajuda. [...]
(In: MARCUSCHI, L. A. Anáfora indireta: o barco textual
e suas âncoras, inédito, fragmento adaptado.)
Uma característica desse texto é a forma como a menina faz as ligaçōes coesivas.
Elabore um texto no qual você proponha alteraçóes para o segundo parágrafo, apresentando
três soluções para o problema dos elos coesivos. Justifique as alteraçôes sugeridas com
apoio de noçóes linguísticas.

Para a análise, os textos foram classificados em três grupos:

a) retextualização e justificativa: Neste tipo de resposta, os formandos apresentam um texto em que há uma retextualização do segundo parágrafo do texto produzido por uma menina de 10 anos (texto-base) e uma justificativa (comentário de análise).

b) justificativa: Neste tipo, os formandos apresentam um texto em que não há a retextualização do segundo parágrafo do texto-base, mas apenas uma justificativa.

c) retextualização: Neste tipo de resposta, os formandos apresentam apenas um texto de retextualização do segundo parágrafo do texto produzido por uma menina de 10 anos. 
O termo "retextualização" foi utilizado nessa classificação para denominar as operações realizadas na passagem do texto escrito para outro texto escrito, conforme explica Marcuschi (2003, p. 46):

a retextualização [...] não é um processo mecânico, já que a passagem da fala para a escrita não se dá naturalmente no plano dos processos de textualização. Trata-se de um processo que envolve operaçôes complexas que interferem tanto no código como no sentido e evidenciam uma série de aspectos nem sempre bem-compreendidos da relação oralidade-escrita.

$\mathrm{O}$ modo de acesso às marcas linguísticas foi orientado pelo paradigma indiciário (GINZBURG, 1991), cujo ponto essencial está na observação de sinais, por meio dos quais é possível encontrar pistas para decifrar uma realidade que se faz representar; no caso dessa análise, a representação que formandos do curso de Letras fazem sobre coesão textual. Não se trata especificamente de uma metodologia para uma análise, mas de um sistema de sinais denominado paradigma indiciário, o qual se presta muito bem à orientação da análise textual, utilizado, entre outros pesquisadores, por Corrêa (1998; 2006).

A utilização desse paradigma indiciário ocorreu especificamente na análise dos textos dos formandos para verificação das formas de manifestação de noções de coesão textual:

(a) por meio da heterogeneidade mostrada marcada nas justificativas (uso de palavras e/ou expressões específicas, uso de palavras e expressões não específicas e uso de palavras e/ou expressões que não fazem menção nem específica nem não específica à coesão textual);

(b) por meio da heterogeneidade mostrada não marcada nas retextualizações (em que se faz "uso" de recursos coesivos e não "menção" à coesão por meio de palavras específicas ou não).

A seguir serão apresentados exemplos dessas formas de manifestação.

\section{Noções de coesão textual por meio da heterogeneidade mostrada marcada}

Foram utilizados para essas formas de manifestação de noções de coesão textual os tipos de respostas Retextualização e justificativa, totalizando cem (100) textos, sendo 38 de alunos da UNIPAR e 62 de alunos da UNIPUB, e 
Justificativa, totalizando 61 textos, sendo 19 de formandos de UNIPAR e 42 de formandos de UNIPUB, já que nesses tipos de respostas havia comentários de análise dos formandos que possibilitariam o surgimento de indícios de noções de coesão textual.

\section{Noções de coesão textual pelo uso de palavras e / ou expressões específicas}

Para este tipo de manifestação foram utilizados 93 textos: 33 textos de formandos de UNIPAR (19 no formato Retextualização e justificativa e 14 no formato Justificativa) e 60 textos de formandos de UNIPUB (32 no formato Retextualização e justificativa e 28 no formato Justificativa).

Os textos classificados apresentaram enunciados com palavras da categoria dos substantivos, advérbios ou adjetivos, como, por exemplo, "coesão", "coesivamente" e "coesivo"; ou expressōes formadas por substantivos e adjetivos, substantivos e substantivos ou adjetivos e adjetivos, por exemplo, "coesão textual", "coesão e coerência", "coesivo e coerente". O resultado desse levantamento pode ser observado nos exemplos ${ }^{2}(1),(2),(3)$ e (4), e seus comentários, a seguir:

(1) A autora comete desvios da norma padrão em seu texto, sobretudo, no segundo parágrafo. Esses desvios poderiam ser evitados se a autora elaborasse períodos mais curtos, pois dessa maneira evitaria as idéias confusas e, ao mesmo tempo, incompletas. O texto seria mais coesivo se os sinais de pontuação fossem empregados de maneira adequada, pois, assim, os períodos seriam divididos e ficariam mais fáceis de serem compreendidos. E se fosse escrito com mais coerência, através de uma melhor elaboração e ordenação das idéias, se tornaria mais correto tanto no sentido sintático, quanto no sentido semântico (texto 43, UNIPAR, grifos nossos).

Em (1), o formando faz uso da expressão "norma padrão" e da palavra "coesivo", as quais foram consideradas, respectivamente, referências à norma culta à coesão textual. Segundo esse formando, a autora do texto-base "comete desvios da norma padrão", isto é, não segue as normas dessa variedade

\footnotetext{
${ }^{2}$ É importante informar que os 10 textos que serão apresentados na análise permanecem na forma original, ou seja, como foram redigidos pelos formandos por ocasião do $\mathrm{ENC/2001.}$
} 
linguística, o que indica que o aluno reconhece a existência de normas e que considera a norma padrão a de maior prestígio. Isso fica mais claro quando o formando aponta o emprego inadequado dos sinais de pontuação como um dos desvios cometidos pela autora do texto-base, emprego este que impede o texto-base de ser "mais coesivo". Ao apresentar tais sugestôes, o formando se comporta como um professor a corrigir o texto da aluna numa representação de uma situação de ensino-aprendizagem. Há, em (1), o estabelecimento de uma relação entre os sinais de pontuação e a função destes como elementos coesivos. Há também a presença de modalizadores, como os adjetivos "confusas", "incompletas", "adequada" e "fáceis", e as formas verbais "fossem" e "ficariam", dentre outras, nos trechos "idéias confusas e (...) incompletas", "[...] se os sinais fossem empregados de maneira adequada" e "[...] ficariam mais fáceis de serem compreendidos". Esses modalizadores conferem ao comentário do acadêmico um juízo sobre o texto-base e, por isso, indicam uma atitude apreciativa do formando, isto é, um julgamento de valor, o que, de acordo com Yaguello (1988), denota juízos sobre a lógica, a clareza e/ou a simplicidade da língua. Tais fatos linguísticos permitem reconhecer em (1) uma noção de coesão textual relacionada com o emprego adequado dos sinais de pontuação e com a norma padrão, o que indica uma atitude normativa e também uma atitude apreciativa por parte desse formando. Nesse texto, há também uma referência à coerência textual por meio da palavra "coerência", a qual está relacionada com a elaboração e ordenação de ideias.

(02) Quando eles foram dormir perceberam que os bezerros começaram a correr, então, foram ver o que estava (acontecendo) assustando os animais. Quando derrepente com uma patada só foram atacados por um carangueijo gigante. Débora a esposa começou a chorar dizendo que queria ir embora. As auteraçóes ocorrentes no segundo palagrafo foram decorrentes pelo seguinte motivo, apesar da menina usar ligaçōes coesivas e o texto apresentar uma coerência de sentido, há um excesso de repetividade, no qual não utilizamos contextualmente, segundo a lingüística se fosse na oralidade poderia falar-se dessa formas, mas, como um texto segue a escrita então deveria seguir a língua padrão, a norma culta (texto 102, UNIPUB, grifo nosso).

Em (02), foi tomada como referência à coesão textual a expressão "ligaçóes coesivas". Há também, nesse texto, uma referência à "coerência de sentido". O enunciador aponta como problema do texto-base o "excesso de repetividade", problema que associa à modalidade falada, mas não à escrita. 
Para esse formando, a modalidade escrita está associada à "língua padrão, a norma culta", e, por isso, não pode haver erro. As expressões "língua padrão" e "norma culta" foram tomadas como referências à gramática normativa. O uso de tais expressões caracteriza a atitude do enunciador como uma atitude normativa, por terem sido empregadas pelos formandos sob a ótica da prescrição, pois, conforme Yaguello (1988), essa atitude indica uma rejeição a formas deterioradas da língua.

(03) Há no texto, repetiçôes de termos e marcadores conversacionais para que o mesmo tenha coesão é necessário retirar os termos em excesso (texto 32, UNIPAR, grifo nosso).

Em (03), o enunciador indica a repetição de termos e de marcadores conversacionais como problemas do segundo parágrafo do texto-base. Segundo ele, esses problemas impedem o texto de ter coesão. Para que esta ocorra, a solução que apresenta é justamente a retirada dos termos em excesso. Nesse enunciado, a referência à coesão textual é feita por meio da palavra "coesão". Essa referência ocorre com marcas que indicam uma atitude apreciativa: "Há, no texto, repetições de termos..." e "[...] é necessário retirar os termos em excesso". De acordo com esses trechos, para que um texto tenha coesão, ele não pode apresentar repetições de termos. Tem-se, então, um indício de uma noção de coesão textual que não está vinculada à repetição de termos.

(04) [...] No segundo parágrafo, repetem várias vezes, o pronome eles; Não precisamos desta repetição. Para um texto ser bastante coerente é preciso: saber empregar a coesão corretamente. Sem repetições desnecessárias etc. (texto 145, UNIPUB, grifo nosso).

Em (04), o enunciador usa os substantivos "repetição" e "repetições" para se referir aos problemas do segundo parágrafo do texto-base e relaciona-os com a coesão textual. O primeiro refere-se à repetição do pronome "eles"; o segundo, às repetições que ocorrem no texto-base de maneira geral. $\mathrm{O}$ uso desses substantivos para caracterizar os problemas do texto-base demonstra que as repetiçôes elaboradas pela autora, uma menina de 10 anos, não são avaliadas como um recurso coesivo, nem mesmo como uma ambiguidade que ela possa causar, mas como um erro. Essa visão é reforçada pelo enunciado "Não precisamos desta repetição" e pelo sintagma "repetições desnecessárias". Observa-se ainda o uso do advérbio "bastante" que exerce o papel de modalizador e reforça a atitude apreciativa do enunciador. Isso posto, a 
referência à coesão textual é feita por meio do termo "coesão". Além disso, o enunciador estabelece uma relação de dependência entre a coerência e a coesão, isso porque apresenta a coerência como uma consequência da coesão quando afirma que "para um texto ser bastante coerente é preciso: saber empregar a coesão corretamente".

Apresentamos, a seguir, a TAB. 1, para uma visualização do levantamento que envolve as palavras e/ou expressões que fazem remissão à coesão textual e o total de ocorrências em que foi detectada a presença de marcas indicadoras de atitudes normativa e apreciativa:

TABELA 1

Coesão e coerência textuais (161 textos)

\begin{tabular}{c|c|c}
\hline $\begin{array}{c}\text { Palavras ou expressões } \\
\text { especificas que remetem à: }\end{array}$ & $\begin{array}{c}\text { Universidades particulares } \\
\text { (UNIPAR) } \\
\text { Total de textos }=57\end{array}$ & $\begin{array}{c}\text { Universidades públicas } \\
\text { (UNIPUB) } \\
\text { Total de textos=104 }\end{array}$ \\
\cline { 2 - 3 } & Qte. de textos & Qte. de textos \\
\hline Coesão textual & 17 & 42 \\
$(51,5 \%)$ & $(70 \%)$ \\
\hline Coesão e & 16 & 18 \\
Coerência textuais & $(48,5 \%)$ & 60 \\
\hline total & 33 & $(57,7 \%)$ \\
\hline
\end{tabular}

Essa tabela mostra uma síntese da primeira forma de manifestação de noções de coesão textual que pode ser relacionada com a noção de heterogeneidade mostrada marcada de Authier-Revuz (1990, 2004). São, ao todo, 33 (57,9\%) textos de formandos provenientes de universidades particulares e $60(57,7 \%)$ textos de formandos provenientes de universidades públicas. Em termos percentuais, não há diferença entre a quantidade de textos de formandos de universidade particular ou pública.

Por esse levantamento, em 51,5\% dos textos de formandos de universidades particulares, a coesão textual não tem relação com a coerência textual, mas 48,5\% apresentam a coesão textual associada à coerência textual. Em relação aos textos de formandos de universidades públicas, predominam noções de coesão textual sem relação com a coerência textual, pois em $70 \%$ desses textos há apenas indícios de noções de coesão textual; somente em $30 \%$ há indícios de coesão textual associada à coerência textual. 
Nesses textos, predominam noções de coesão e coerência textuais marcadas pela presença de expressões normativas e de modalizadores que indicam, respectivamente, atitudes normativa e apreciativa por parte do sujeito enunciador. Tais marcas representam casos de heterogeneidade mostrada marcada e, por isso, são indicadoras de uma relação dialógica discursiva: a relação do discurso normativo com o discurso apreciativo.

Esse resultado permite refletir sobre os fatores causadores das diferentes noções de coesão textual. O que se observa é que as referências à coesão e à coerência textuais no discurso desses formandos são indícios de noções de coesão textual que se mostram diferentes por haver influência de teorias linguísticas diferentes. Ao relacionar essas noções de coesão textual com a situação na qual esses textos foram produzidos, pode-se dizer que elas são resultado da relação dialógica entre os formandos, o texto da menina que integra a questão da prova do ENC/2001 e a banca examinadora. Pode-se dizer também que há a relação entre os discursos que constituem esses sujeitos e os posicionamentos por eles assumidos (consciente ou inconscientemente) nos diversos campos de saber. Nessa relação, motivados pela questão da prova, os formandos de UNIPAR e de UNIPUB analisaram o texto-base, apontando problemas, entre os quais predomina a repetição de termos, assim como soluções para esses problemas. Assim, se nessas noções a coesão está relacionada com o emprego adequado de elementos coesivos (pronome, conjunções etc.), o emprego inadequado desses elementos indica a falta de coesão que, segundo os formandos, ocorre no texto-base.

\section{Noções de coesão textual pelo uso de palavras e / ou expressões não específicas}

Neste modo de manifestação, a presença de indícios de noções de coesão textual foi observada em 60 (sessenta) textos, sendo 20 (vinte) textos de formandos de UNIPAR (15 de Retextualização e justificativa e 5 de Justificativa), e 40 (quarenta) de formandos de UNIPUB (28 de Retextualização e justificativa e 12 de Justificativa).

Nesta forma de manifestação, a seleção lexical efetuada pelos formandos também foi considerada como indício de noções de coesão textual. Entretanto, neste conjunto de textos não há o uso de marcas explícitas específicas, mas de palavras e/ou expressões não específicas, por exemplo, "logo", "conjunção", "pronome eles", "há repetições", "muita repetição", "ideia de resultado" etc., já que esse uso também pode ser considerado como fruto de um posicionamento em um campo discursivo (MAINGUENEAU, 1991, p. 17-18). 
No levantamento realizado, embora não tenha havido referências explícitas à coesão textual, houve referência à coerência textual com marcas que indicam uma atitude apreciativa do enunciador. Vejamos alguns textos com seus respectivos comentários:

(05) No texto "O outro lado da ilha", nos mostra algumas falhas na colocação de certas palavras, como: que; eles; para; onde a menina utilizou repetidas vezes. Os processos discursivos não foi usado, sendo assim; faltou diálogo, mas não verbalmente. Por ela não ter uma linguagem culta, não quer dizer que está incorreto sua produção textual, porque a mesma conseguiu manter relação entre o receptor (texto 48, UNIPAR, grifo nosso).

De acordo com (05), o enunciador apresenta algumas falhas no textobase, como o emprego de algumas palavras repetidas, o que já indica uma postura apreciativa. O formando acusa a autora de não utilizar os processos discursivos no texto-base, por não haver diálogos nesse texto. Faz, então, referência à norma culta, afirmando que o não uso de linguagem culta pela autora no texto-base não o torna incorreto, já que conseguiu "manter a relação com o receptor", sugerindo que a eficácia da comunicação dispensa o uso de uma linguagem culta. Como indícios de uma noção de coesão textual, foram consideradas as palavras "que", "eles" e "para”. Segundo essa noção, para haver coesão é preciso que determinadas palavras (pronomes e preposiçôes) sejam empregadas adequadamente.

(06) As alterações ocorridas no parágrafo foi para que não se repetisse alguns termos várias vezes sem necessidade, para que a ordem dos acontecimentos ficasse mais sequenciada e coerente(texto 97, UNIPUB, grifo nosso).

Em (06), o enunciador, para justificar as alterações propostas para o segundo parágrafo do texto-base, também aponta a repetição como problema do texto-base. Segundo ele, com as alterações, o texto será mais coerente. A associação do trecho "não se repetisse alguns termos" com "ordem [...] mais sequenciada", embora deixe pistas de uma noção de coesão textual, vem, em seu conjunto, submetida à função de propiciar uma "ordem [...] mais [...] coerente". A atitude apreciativa do enunciador é marcada pela redundância "repetisse alguns termos várias vezes" e pelo trecho "mais sequenciada e coerente". Tem-se, assim, uma noção implícita de coesão textual relacionada com a coerência textual, uma vez que o enunciador sugere a utilização adequada 
de termos que mantenham a "ordem dos acontecimentos" e a sequência "coerente" do texto.

De acordo com o resultado desse levantamento, também há textos em que a noção de coesão textual está implícita ou só explícita em função da situação (um exame com uma questão em que se propõe o desenvolvimento de uma atividade específica e de um assunto determinado). Entre esses últimos, figuram textos em que ocorreram palavras que fazem remissão implícita à coesão textual (17 (85\%) textos de formandos de UNIPAR e 34 (85\%) textos de formandos de UNIPUB) e explícita à coerência textual (3 (15\%) textos de formandos de UNIPAR e 6 (15\%) de formandos de UNIPUB). De acordo com o total de textos, percentualmente, pode-se perceber um equilíbrio em ambas as esferas universitárias. É significativo o fato de os formandos empregarem palavras que fazem referência explícita à coerência textual nos comentários sobre o texto-base e a questão da prova do ENC/2001 tratar de mecanismos coesivos empregados pela autora desse texto. Parece sugerir que as causas desse fato podem ser duas: 1) os formandos confundiram a noção de coesão textual com a de coerência textual, isto é, misturaram as noções; 2) os formandos concebem a coerência textual como uma consequência de um texto bem formado quanto às ligaçóes coesivas.

O resultado da análise desse conjunto de textos sugere que esses formandos apresentam uma noção de coesão textual que ocorre de forma implícita em um discurso em que se apontam problemas no texto-base. Esse apontamento de problemas indica o predomínio de uma atitude apreciativa. Com isso, pode-se dizer que, nesses textos, também há uma reprodução de um discurso didático e que há evidências de um discurso que procura se apropriar de uma terminologia mais técnica, considerada as condições de produção dessas respostas: o ENC/2001.

\section{Forma de manifestação pelo uso de palavras e / ou expressões que não fazem menção nem específica nem não específica à coesão textual}

Nesta forma de manifestação estão incluídos os textos que não integraram as análises anteriores por não apresentarem marcas - específicas ou não - de coesão textual. São quatro textos de formandos de UNIPAR, sendo os quatro de Retextualização e justificativa, e quatro textos de formandos de UNIPUB, sendo dois de Retextualização e justificativa e dois de Justificativa. Nesses textos, os formandos empregam palavras e/ou expressóes que não 
fazem referência nem específica nem não específica à coesão textual. Entretanto, esses textos apresentam indícios que remetem à coerência textual, por meio das palavras "coerência" e "coerente"; à gramática normativa, por meio das expressões "gramática normativa" e "normas / regras da língua culta"; e à linguística, por meio da palavra "lingüística". Por isso, tais marcas foram tomadas como índices da presença do outro e, assim, também foram relacionadas com a noção de heterogeneidade mostrada marcada. Vejamos dois exemplos:

(07) Just: Somente com a mudança da sequência dos acontecimentos e das ações das personagens é possível criar novas opções mais coerentes (texto 22, UNIPAR, grifo nosso).

(08) [...]Soluções

** Ajudar o bebâdo

*Esquecer o ocorrido e curtir suas férias;

* Saborear a natureza;

Acrescentei, um bebâdo neste texto, porque é mais fácil encontrar um bebâdo em uma ilha, do que caranguejo gigante (texto 81, UNIPUB).

Em (07), o formando refere-se à sequência de acontecimentos do textobase para sugerir uma mudança e, assim, torná-lo "coerente", fazendo uma remissão à coerência textual.

Já em (08), o formando brinca com a situação, construindo um comentário jocoso.

De maneira geral, nesse conjunto de textos, houve o predomínio de uma retextualização do segundo parágrafo do texto-base e de comentários com a indicação de problemas nesse texto. Entre os problemas estão: "ambiguidade", "vocabulário escasso", "falta de sequência das ideias". A indicação desses problemas, embora em menor número, não difere dos problemas apontados nas análises feitas com os demais textos nas análises já apresentadas. As soluçôes apresentadas foram: "organização das ideias", "uso adequado de palavras", "a conclusão deveria ser mais concisa”.

Com base na análise, observamos que nas justificativas desse grupo de textos não há indícios de noçôes de coesão textual. Essa ausência se destaca pela presença de marcas que remetem à coerência textual, à linguística e à gramática normativa. Essas ocorrências também indicam uma tentativa de apropriação de um discurso mais técnico. A presença de modalizadores no apontamento de problemas e de soluçôes também é visível, por exemplo, "uso desnecessário", 
"uso adequado", "vocabulário escasso", "a conclusão deveria ser mais concisa". Pode-se dizer, com isso, que, nesse conjunto de textos, também vigora um discurso marcado por atitudes normativa e apreciativa do enunciador, uma vez que predomina o apontamento de problemas no texto-base. Tem-se, então, a presença de um discurso didático-pedagógico.

\section{Noções de coesão textual por meio da heterogeneidade mostrada não marcada}

Para esta análise, partimos do pressuposto de que nas retextualizações do segundo parágrafo do texto-base, ao empregar recursos coesivos, o formando não apresenta noções de coesão textual de modo explícito, mas de modo mais opaco, mais próximo da noção de heterogeneidade mostrada não marcada e do próprio conceito de heterogeneidade constitutiva de Authier-Revuz (1990, 2004). Consideramos, portanto, que subjazem, nas retextualizaçôes, por meio do uso de recursos coesivos, noções de coesão textual.

Foram utilizados 49 textos das respostas classificadas como Retextualização, formato no qual não há justificativas dos formandos do curso de Letras, mas apenas uma retextualização do segundo parágrafo do texto-base, sendo 19 de alunos de UNIPAR e 30 de alunos de UNIPUB.

De acordo com o levantamento, os procedimentos mais utilizados pelos formandos ao retextualizarem o segundo parágrafo do texto-base foram:

1) elipse: consiste no apagamento do pronome "eles", embora ele possa ser identificado pela desinência verbal na flexão do verbo principal.

2) exclusão: consiste na eliminação de um ou mais elementos formais representados por palavras ou expressóes.

3) inclusão: consiste na inclusão de outros elementos, os quais podem ser representados por uma palavra ou expressão, por uma oração ou por um período que não havia no texto-base e por sinais de pontuação como a vírgula e o ponto final.

4) manutenção: consiste na repetição / manutenção dos mesmos elementos do texto-base na retextualização.

5) substituição: consiste na troca de um elemento formal por palavra ou expressão, de forma que o sentido se mantenha.

Os procedimentos mais utilizados pelos formandos de UNIPAR foram: $\left.1^{\circ}\right)$ elipse: 38 ocorrências $\left.(26,4 \%) ; 2^{\circ}\right)$ exclusão: 37 ocorrências 
$(25,7 \%)$; $\left.3^{\circ}\right)$ substituição: 24 ocorrências $(16,7 \%)$; $\left.4^{\circ}\right)$ manutenção: 23 ocorrências (16\%); 50) inclusão: 22 ocorrências (15,2\%).

Ao utilizarem esses procedimentos, predominantemente os recursos da elipse e da exclusão, os formandos eliminaram a repetição de pronomes e de conjunçōes do texto-base. Cabe lembrar que esse fato pode ser comparado com o resultado da análise das justificativas dos textos Retextualização e justificativa e Justificativa, em que a repetição de pronomes e conjunções teve um número maior de ocorrência. Segundo os dados levantados, os problemas mais apontados no texto-base pelos formandos de ambos os tipos de universidades foram: a repetição de pronomes e conjunções, a falta de pontuação, a falta de coesão e de coerência e a falta de referente para a oração "Débora que era sua esposa". Em relação aos demais problemas, houve uma tentativa dos formandos em resolvê-los. Isso significa que, ao utilizarem os recursos coesivos, os formandos tentaram estabelecer a coesão e a coerência (que diziam faltar) no texto-base.

Por sua vez, quanto aos textos de formandos de UNIPUB, os procedimentos mais utilizados foram: $1^{\circ}$ ) exclusão: 65 ocorrências $(26,4 \%)$; $2^{\circ}$ ) elipse: 57 ocorrências $\left.(23,2 \%) ; 3^{\circ}\right)$ manutenção: 49 ocorrências $(20 \%)$; 4 ) inclusão: 38 ocorrências $(15,4 \%) ; 5^{\circ}$ ) substituição: 37 ocorrências (15\%). Embora essa ordem de recursos seja diferente da ordem ocorrida nos textos de formandos de UNIPAR, com a aplicação desses recursos, os formandos solucionaram parte do problema dos elos coesivos do texto-base, eliminando e omitindo as repetições.

$\mathrm{Na}$ exposição a seguir, apresentamos alguns exemplos com seus respectivos comentários:

(09) "Quando todos foram dormir, perceberam que os bezerros começaram a correr, então, quando eles foram ver o que estava assustando-os depararam-se com um caranguejo gigante que atacavaos com patadas. Conseqüentemente, Débora começou a chorar, dizendo que queria ir embora." (texto 57, UNIPAR).

Em (09), o enunciador utilizou os seguintes recursos: substituição, inclusão, elipse, manutenção, exclusão. Com a utilização desses recursos, com predominância da inclusão e da exclusão, houve a eliminação da repetição de pronomes e de conjunções. A elipse do pronome "eles" e de vírgulas chama a atenção para a preocupação do formando em solucionar o problema da repetição de termos e a falta de pontuação do texto-base. Em relação à oração "que era sua esposa", nota-se que o formando, ao eliminá-la, provavelmente 
para resolver o problema apontado da falta de um antecedente para o sintagma "sua esposa", põe em destaque o substantivo "Débora", para o qual também não há um antecedente explícito. Isto quer dizer que ele tentou resolver o que considerava um problema, mas reproduziu a mesma expectativa de preenchimento com que contou a autora do texto-base. Um leitor que acompanha a narrativa pode, por inferência, relacionar o termo "Débora" com a expressão nominal antecedente "uma família" (primeiro parágrafo da narrativa). Nesse caso, "Débora" surge como um referente novo, mas conhecido, que se ancora na expressão "uma família". Trata-se de um caso de anáfora indireta, que consiste, segundo Marcuschi (2000), na interpretação referencial de uma expressão nominal definida ou pronome sem que lhe corresponda um antecedente, ou subsequente, na superfície textual. O que ocorre, então, é a ativação de um novo referente que não necessita de um antecedente explícito no texto para ser compreendido, por isso constitui um processo de referência implícita. Podese concluir que, ao utilizar recursos coesivos na retextualização, o formando procura estabelecer a coesão que julga faltar no texto-base.

No exemplo,

(10) Quando eles foram dormir perceberam que os bezerros começaram a correr e algo estava assustando. De repente um caranguejo os atacou. Débora começou a chorar dizendo que queria ir embora (texto 181, UNIPUB),

pode-se perceber a utilização dos recursos de manutenção, de elipse e de exclusão, em que esta predominou. Com esses recursos, o formando eliminou a repetição de termos. No entanto, com a exclusão da oração que "era sua esposa", possivelmente, na tentativa de resolver a falta de antecedente para o sintagma "sua esposa", e com a manutenção do nome "Débora" na narrativa, tem-se um termo como referente novo. Mantém-se, assim, o que ocorreu nos textos de alunos de UNIPAR, a ocorrência de uma anáfora indireta, ou seja, uma expressão nominal definida sem um antecedente explícito, fenômeno que já havia antes da exclusão da oração "que era sua esposa”. Com a aplicação desses recursos, tem-se estabelecida uma relação coesiva no parágrafo, o que indica uma noção de coesão textual.

Pode-se observar, por essa análise, que os dois procedimentos mais utilizados pelos alunos, na esfera particular, foram a elipse e a exclusão; já na esfera pública, foram a exclusão e a elipse. Nos procedimentos seguintes também houve uma inversão: substituição, manutenção e inclusão (UNIPAR) e manutenção, inclusão e substituição (UNIPUB). O que não pode passar 
despercebido é o fato de o recurso da manutenção figurar nas duas esferas universitárias, uma vez que a manutenção consiste em manter ou repetir termos e expressōes, procedimento tido como um erro quando da análise dos textos classificados como formas de manifestação de noções de coesão por meio da heterogeneidade mostrada marcada.

Diante desse resultado, a adoção de recursos coesivos pelos formandos para atender à questão do ENC / 2001 indica que noções de coesão textual subjazem nas retextualizações propostas. Sintetizando essas noções, a elipse, a exclusão, a inclusão, a manutenção e a substituição são recursos coesivos que podem ser aplicados no texto para estabelecer sua conectividade e, assim, relações de sentido. Trata-se de uma referência mais velada à coesão textual e por isso foi considerada mais próxima da noção de heterogeneidade mostrada não marcada. Pode-se dizer também que o uso de tais recursos é resultado da relação dialógica entre os formandos e a questão da prova, a qual representa uma instituição federal (Ministério da Educação) e cuja resposta foi avaliada por uma banca; e entre os formandos e o texto-base, o qual foi produzido por uma menina de dez anos. Tem-se, assim, uma relação interacional dialógica entre os interlocutores, que reflete a relação interdiscursiva que emerge dos textos desses alunos por meio dos recursos coesivos.

Dessa forma, as retextualizações produzidas pelos formandos, embora sem palavras específicas ou não específicas que façam menção à coesão textual, podem ser consideradas portadoras de indícios de noções de coesão textual que se representam pelo uso de recursos coesivos. Por meio desses recursos, os alunos procuram desenvolver um processo que envolve operações complexas, as quais interferem na construção do texto e de seu sentido (MARCUSCHI, 2003). No uso desses recursos, os formandos estabelecem uma relação de alteridade com um discurso mais técnico sobre os elementos coesivos, a sua função de estabelecer relações de sentido entre elementos do texto e os recursos coesivos empregados, num processo de coesão referencial e sequencial.

\section{Conclusão}

Orientamos esta pesquisa para uma abordagem enunciativo-discursiva, apoiando-nos no conceito de interacionismo dialógico de Bakhtin (1997, 2003) e no conceito de heterogeneidade(s) enunciativa(s) de Authier-Revuz (1990; 2004).

No que se refere à relação entre interlocutores, ficaram expostas as representações que os formandos fazem sobre a autora do texto-base, sobre a 
banca avaliadora do exame e sobre si mesmos. Por meio dessa representação, constroem para si uma imagem, já cristalizada, de um professor a corrigir o texto de um aluno, na provável intenção de se submeterem - e assim passarem a imagem de professores - à avaliação de uma banca examinadora, representada, por sua vez, como a instituição máxima de regulação da educação, o próprio Ministério da Educação.

No tocante à relação entre discursos, conforme as vozes que atravessam o discurso desses formandos, destacam-se o discurso didático-pedagógico, no qual se insere um discurso prescritivo-normativo, e o científico. A voz do discurso didático-pedagógico se caracteriza por reproduzir a voz de um professor que se póe a corrigir o texto produzido por uma menina de 10 anos e pela apropriação de uma meta-linguagem que confere a autoridade a esse professor a um dizer institucionalizado; a voz do discurso científico se caracteriza pela utilização de um discurso mais técnico, de uma terminologia mais precisa sobre aspectos da língua para se referir à coesão e à coerência textuais, visando a atender à questão do ENC / 2001, que solicitava a elaboração de uma justificativa para as alterações sugeridas com apoio de noções linguísticas. Por meio desses discursos, o formando busca conferir ao texto consistência e credibilidade.

A partir da análise dos procedimentos adotados por esses estudantes, manifestaram-se no discurso desses formandos diversas noções de coesão textual, entre as quais pode ser formulada a seguinte noção: a coesão textual refere-se ao emprego adequado de elementos coesivos, entre eles, os sinais de pontuação. Segundo essa noção, a repetição não é considerada elemento de coesão e a coerência passa a ser uma consequência do emprego desses elementos. No entanto, essa noção tem ancoragem numa abordagem tradicional de linguagem, uma vez que predomina no discurso desses formandos atitudes normativa e apreciativa. Desse modo, a apropriação da teoria se dá pela via de uma ancoragem estranha à concepção de coesão evocada nos textos, permanecendo a dúvida quanto a estar esta última vinculada a um saber repassado no ensino superior ou à habilidade de atribuição de um sentido tradicional para uma noção colhida com base na simples menção presente na questão do exame.

Porém, o dado mais significativo desta pesquisa não se situa no conteúdo que o discurso desses formandos apresenta sobre coesão textual, mas nos modos pelos quais os formandos se manifestam sobre esse tema. Embora um conjunto maior de textos com justificativas apresente uma noção de coesão 
difusa e misturada à gramática, à linguística textual e à linguística, mais significativo para esta pesquisa se torna o fato de noções correlatas de coesão se revelarem por meio do uso dos recursos coesivos da elipse, da exclusão, da inclusão, da manutenção e da substituição nas retextualizações do segundo parágrafo do texto-base. Consideramos que há uma complementaridade dessas formas de manifestação das noções de coesão, de modo que as formas de heterogeneidade mostrada marcada e não marcada representam-se, respectivamente, segundo dois modos de assunção da perspectiva prescritivonormativa: em formas de distanciamento que definem o uso feito pelo outro (nas Justificativas) e em formas de assunção, no uso exemplificado pela própria escrita (nas Retextualizaçôes) do formando.

\section{Referências}

AUTHIER-REVUZ, J. Heterogeneidade(s) enunciativas(s). Cadernos de Estudos Linguisticos, Campinas, n. 19, p. 25-42, jul./dez. 1990.

AUTHIER-REVUZ, J. Heterogeneidade mostrada e heterogeneidade constitutiva: elementos para uma abordagem do outro no discurso. In: . Entre a transparência e a opacidade: um estudo enunciativo do sentido. Porto Alegre: EDIPUCS, 2004. p. 11-80.

BAKHTIN, M. / VOLOCHINOV, V. [1929]. Marxismo e filosofia da linguagem. Trad. Michel Lahud e Yara. F. Vieira. 8. ed. São Paulo: Hucitec, 1997.

BAKHTIN, M. Estética da criação verbal. Trad. Paulo Bezerra. 4. ed. São Paulo: Martins Fontes, 2003.

BARROS, D. L. P. Dialogismo, polifonia e enunciação. In: ; FIORIN, J. L. (Org.). Dialogismo, polifonia, intertextualidade em torno de Bakhtin. São Paulo: Edusp, 1994. p. 1-9.

BARROS, D. L. P. Contribuição de Bakhtin às teorias do discurso. In: BRAIT, B. (Org.). Bakhtin: dialogismo e construção do sentido. 2. ed. Campinas: Editora da Unicamp, 2005. p. 25-36.

CORRÊA, M. L. G. A heterogeneidade na constituição da escrita: complexidade enunciativa e paradigma indiciário. Cadernos da F.F.C. Marília (SP), v. 6, n. 2, p. 165-185, 1998.

CORRÊA, M. L. G. A produção escrita de formandos em Letras: a experiência do provão. In: OLIVEIRA, M. de (Org.). Lingua Portuguesa em São Paulo: 450 anos. São Paulo: Associação Editoria Humanitas, 2006. p.141-165. 
GINZBURG, C. Mitos, emblemas, sinais: morfologia e história. Trad. Frederico Carotti. São Paulo: Companhia das Letras, 1991. p. 143-179.

MAINGUENEAU, D. L'Archive. In: _. L'Analyse du discours: introduction aux lectures de l'archive. Paris: Hachette, 1991. p. 09-28.

MARCUSCHI, L. A. Anáfora Indireta: o barco textual e suas âncoras. Revista de Letras da UFPR. Curitiba, v. 56, n. jul / dez, p. 217-258, 2001. Versão revista do texto apresentado na IV Jornada do CELSUL-UFPR, nov. 2000.

MARCUSCHI, L. A. Da fala para a escrita: atividades de retextualização. 4. ed. São Paulo: Cortez, 2003.

YAGUELLO, M. Le sentiment de la langue. In: . Catalogue des idées recues sur la langue. Paris: Editions du Seuil, 1988. p. 11-14. 